\title{
INFLUENCE OF ROOTING MEDIA AND INDOLE-3-BUTYRIC ACID (IBA) CONCENTRATION ON ROOTING AND GROWTH OF DIFFERENT TYPES OF CONOCARPUS ERECTUS L. STEM CUTTINGS
}

\author{
S.S.A. Abdel-Rahman \\ Ornamental Plants and Landscape Gardening Dept., Fac. Agric., Assiut Univ., Egypt
}

\begin{abstract}
The present study was conducted to evaluate the influence of rooting media (clay, peat moss + sand, peat moss + perlite and vermiculite), cutting types (tip, middle and basal) and different concentrations of indole-3-butyric acid (control, 50, 100 and 200 ppm IBA) on the rooting and growth of Conocarpus erectus L. stem cuttings. The experiment was laid out in a split-split-plot design, with three replicates. The obtained results showed that vermiculite was the best rooting medium used for improving the rooting percentage, root number, root length, stem length, branch number and leaf number per rooted cutting, followed by peat + perlite $(1: 1$ in $\mathrm{v} / \mathrm{v})$ and peat + sand (1:1 in $\mathrm{v} / \mathrm{v})$, respectively comparing with clay soil which recorded the lowest values. The tip cutting was superior to the middle and basal ones in all rooting media used, especially in vermiculite medium. Among IBA concentrations used, cuttings treated with IBA at $100 \mathrm{ppm}$ produced significantly better rooting (42.9\%) than $50 \mathrm{ppm}(36.3 \%)$, $200 \mathrm{ppm}(36.0 \%)$ and untreated cuttings (23.1\%). The greatest rooting percentage (95.0\%) and the best root and growth characteristics as well as the highest endogenous contents of phenols, indole acetic acid (IAA) and the lowest abscisic acid (ABA) contents were obtained from tip cuttings treated with IBA at $100 \mathrm{ppm}$ and planted in vermiculite substrate. Moreover, the combined treatment of $100 \mathrm{ppm}$ IBA and vermiculite substrate significantly improved the rooting percentage, root and growth measurements of middle and basal cuttings as well as gave the highest $\mathrm{C} / \mathrm{N}$ ratio in basal cutting tissues compared to the same cutting types combined with the other rooting media and IBA concentrations. Hence, it could be recommended to treat the different types of $C$. erectus stem cuttings with IBA at $100 \mathrm{ppm}$ and planting in vermiculite medium for improving rooting, quality and growth of cuttings.
\end{abstract}

Scientific J. Flowers \& Ornamental Plants, 7(3):199-219 (2020).

Received: 17/6/2020

Accepted:

Key words: Conocarpus erectus, rooting media, IBA concentration, cutting type.

\section{INTRODUCTION}

Buttonwood (Conocarpus erectus, L.) belonging to Combretaceae family is an evergreen shrub or tree, which is native to Florida's mangrove forest ecosystem in North America and shores of tropical America and Africa (Dhaarani et al., 2017).
It tolerates diseases, insects, light frosts, pests, salinity, poor drainage and drought (Little, 1983), as well as desert heat and it can also grow in very low fertility soils (Nelson, 1996). It is planted as a hedge and shade tree in yards, streets, parking lots and parks and it also protects the soil during storm and helps to fix dunes (Gilman and 
Watson, 1993). Wood is most widely used for high-grade charcoal (Morton, 1981). Bark has been used for tanning leather and it contains about $16-18 \%$ tannin. Besides, the plant is used as animal food (Suleiman et al., 2005) and in a number of medicinal properties including anticancer, antiviral, anti-diabetic, antioxidant, antibacterial and antifungal activities (Yasin and Al-Azawi, 2019).

Conocarpus plant is mainly propagated by stem cuttings (Mohamed et al., 2014). Previous researches have shown that the rooting success of semi- and hard-wood cuttings in Conocarpus is very low (AlDulaimy, 2016; Abdel-Rahman et al., 2020). The vegetative propagation success by stem cuttings is affected by several important factors. Among these different factors, the rooting media, cutting types, the type and concentration of auxins used, season, hormonal and physiological status of the mother plant, carbohydrates, phenols, the presence of leaves on cuttings, humidity, genetic characteristics and many other factors (Hartmann et al., 2014; Kumar et al., 2019).

Rooting medium is the most important factor which plays a main role in quality, rooting and growth of cuttings in many plants (Rajkumar et al., 2017; Kumar et al., 2019). The selection of the suitable rooting media depends on the species, cutting type, propagation season, growing conditions, propagation system used and physicochemical characteristics of the substrate as well as on its cost and availability (Sardoei, 2014; Eed et al., 2015). A good propagation medium would provide sufficient support to the plant, nutrients and hold plant available water, allow oxygen diffusion to the roots and permits gaseous exchange between the roots and atmosphere outside the rooting media (Manila et al., 2017; Dawa et al., 2018). Lack of one or more of these useful characteristics lead to lower rootability of cuttings (Dvin et al., 2011). The best rooting media must have a $\mathrm{pH}$ favorable to optimum nutrient availability and texture which permits unrestricted gaseous exchange and water movement for the proper root development (Larson, 1980). However, many mixtures have been used as media for plant propagation. Most propagators use a combination of organic and mineral components such as peat-perlite, peatvermiculite-perlite, peat-sand, peat-rockwool (Sabalka, 1986). Sometimes the mineral component is used alone (e.g., vermiculite, perlite, sand, rockwool) or in combination (e.g., vermiculite-perlite, sand-polystyrene). Sufficient coarse mineral component such as perlite or coarse sand should be added to improve aeration (Hartmann et al., 2014). Several studies have indicated the positive effects of vermiculite, peat, perlite and sand in improving the rootability of cuttings (Ansari, 2013; Rajkumar et al., 2017; Jaleta and Sulaiman, 2019). Vermiculite has been found to considerably enhance the rooting and growth of cuttings in many species, especially when combined with IBA or NAA treatments compared to the other rooting media (Hosseini et al., 2004; Rajkumar et al.; 2016; Peña-Baracaldo et al., 2018). On the other hand, the combination of peat moss with perlite or sand is suitable for rooting and growth of cuttings in some plants compared to the other rooting media (Tsipouridis et al., 2005; Exadaktylou et al., 2009; Jaleta and Sulaiman, 2019). However, different rooting media cause variations in rooting percentage, root and vegetative growth characteristics of cuttings (Hartmann et al., 2014).

Exogenous auxins application, mainly IBA plays a crucial role in enhancing of rooting efficiency and also quality of stem cuttings in nurseries (Peña-Baracaldo et al., 2018; Kumar et al., 2019). However, it was observed that the type and concentration of exogenous auxins applied play an important role in rooting and growth of cuttings depending on plant species (Hartmann et al., 2014; Daskalakis et al., 2018). In this concern, Mohamed et al. (2014) reported that treatment of Conocarpus erectus cuttings with IBA at 3000 ppm remarkably 
enhanced the rooting percentage comparing with 2000 ppm IBA and untreated cuttings. In another study, Al-Tohaty et al. (2014) cleared that treatment of Conocarpus lancifolius cuttings with IBA at 500 and 1000 ppm significantly increased the rooting and growth of cuttings compared to untreated cuttings. The highest rooting percentage and the best root and shoot characteristics were resulted from cuttings treated with IBA at $500 \mathrm{ppm}$. Moreover, Elgalby et al. (2011) stated that treating cuttings of Conocarpus lancifolius with 500 ppm IBA improved both root length and primary root number, while 1000 ppm IBA increased the secondary root number.

On the other hand, stem cutting types have been reported strongly influence the rooting success (Caldwell et al., 1988). This was may be correlated with anatomical structure of the stem or difference in chemical composition of the plant along the stem (Hartmann et al., 2014). Some investigators revealed that the tip cuttings of Conocarpus spp. rooted better than middle or basal ones (Al-Dulaimy, 2016; AbdelRahman et al., 2020).

There is no available information in the literature with respect to vegetative propagation by use of rooting media, cutting types and auxin concentrations for induction of rooting of $C$. erectus cuttings. Therefore, the current study aimed to evaluate the rooting and growth of different types of $C$. erectus stem cuttings in response to rooting media and the concentration of IBA that will enhance successful establishment of the plant in the nursery.

\section{MATERIALS AND METHODS}

The current investigation was conducted at the Experimental Farm of Floriculture, Faculty of Agriculture, Assiut University, Egypt, during the two successive seasons of 2016 and 2017 to evaluate the influence of rooting media and to optimize the concentration of indole-3-butyric acid (IBA) on rooting and growth of different types of C. erectus stem cuttings.

Healthy 6-year-old mother plants of $C$. erectus were used as source of cuttings. On March $1^{\text {st }}$ of both seasons, three cutting types (tip, middle and basal) were taken from oneyear-old branches of $C$. erectus. These cuttings had a uniform length (15 cm long) and the mean thicknesses were 0.5, 0.8 and $1.2 \mathrm{~cm}$ for the terminal, middle and basal cuttings, respectively in both seasons. The different cutting bases were soaked in aqueous solutions of 50, 100 and 200 ppm IBA for 20 hours, while the control group was soaked in distilled water. After treating cuttings with IBA, they were inserted in plastic pots of $20 \mathrm{~cm}$ diameter filled with four different rooting media i.e. clay, peat moss + sand (1:1 in $\mathrm{v} / \mathrm{v})$, peat moss + perlite $(1: 1 \mathrm{in} v / v)$ or vermiculite. The sand was washed well before use. The constituents and properties of the rooting media used were estimated according to the methods described by Jackson (1973) as shown in Table (1). The experiment was conducted under saran house and covered by tightly

Table 1. Some physical and chemical analysis of the rooting media used at the beginning of the experiment (average of 2016 and 2017 seasons) *

\begin{tabular}{|c|c|c|c|c|c|c|c|c|c|c|}
\hline \multirow{2}{*}{$\begin{array}{l}\text { Rooting media } \\
\text { (v/v ratio) }\end{array}$} & \multicolumn{6}{|c|}{ Soluble ions (meq/100 g substrate) ${ }^{*}$} & \multirow{2}{*}{$\begin{array}{c}\mathrm{K}^{+} \\
\text {(mg/100 g } \\
\text { substrate) }\end{array}$} & \multirow[b]{2}{*}{$\mathbf{p H}^{* *}$} & \multirow{2}{*}{$\begin{array}{l}E^{* * *} \\
\left(\mathrm{dS} \mathrm{m^{-1 }}\right)\end{array}$} & \multirow{2}{*}{$\begin{array}{c}\text { Organic } \\
\text { matter } \\
(\%)\end{array}$} \\
\hline & & Cation & & & Anions & & & & & \\
\hline Clay & 3.11 & 254 & 3.64 & 3.19 & 356 & 2.54 & 0.24 & 8.21 & 1.52 & 1.71 \\
\hline Peat + sand (1:1) & 1.38 & 0.85 & 1.82 & 1.42 & 1.61 & 1.02 & 0.17 & 6.61 & 0.92 & 34.15 \\
\hline Peat + perlite (1:1) & 0.89 & 1.26 & 0.98 & 0.85 & 1.25 & 1.03 & 0.39 & 5.86 & 0.61 & 50.34 \\
\hline Vermiculite & 0.92 & 1.34 & 0.34 & 0.75 & 0.80 & 1.05 & 0.42 & 7.76 & 0.28 & 1.12 \\
\hline
\end{tabular}

${ }^{*}$ Each value represents the means of 3 replicates

*** Soil-water suspension (1:5)

*** Soil-water extract $(1: 5)$. 
polyethylene film to maintain high relative humidity.

The experiment was arranged in a splitsplit-plot design, with three replicates. Rooting media (clay, peat + sand, peat + perlite and vermiculite) represented in the main plots, meanwhile cutting types (tip, middle and basal) and IBA concentrations (control, 50, 100 and 200 ppm) represented the sub-plots and sub-subplots, respectively. Each experimental unit contained 10 cuttings.

The cuttings in present investigation were held in rooting substrates almost three months after IBA treatments. Data were recorded on the rooting percentage, root number, root length, stem length, branch number and leaf number per rooted cutting. Then, one centimeter sample of the basal end representing each treatment were taken and dried for determination of total carbohydrates, nitrogen and total phenols contents. Total carbohydrates percentage was estimated colorimeterically using anthrone sulphuric acid method described by Hansen and Moller (1975). Total nitrogen content was determined by semi-micro Kjeldahl method according to Bzlack et al. (1982). Then, carbohydrates/nitrogen ratio (C/N ratio) was calculated. The total phenols content was estimated colorimeterically by Folin ciocalteau reagent (FCR) method (Vasco et al., 2008).

Endogenous hormones of IAA and ABA in tissues of fresh cutting bases were isolated by extraction with volatile organic solvents, and quantified according to Zhang et al. (1998) using $\mathrm{C}_{18}$ reversed-phase high performance liquid chromatography (RPHPLC) column. It was isocratically eluted at

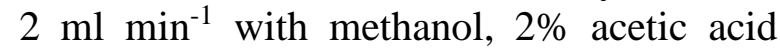
and $\mathrm{H}_{2} \mathrm{O} \quad(40: 20: 20)$ as mobile phases, detection was with an absorbance monitor operating at $254 \mathrm{~nm}$.

Data obtained during the two seasons were subjected to the statistical analysis using Statistix 8.1 analytical software. Means were compared using the least significant differences (L.S.D.) test at 5\% level of probability according to Gomez and Gomez (1984).

\section{RESULTS AND DISCUSSION}

\section{Rooting percentage:}

The obtained results in Tables (2 and 3) clearly show that rooting percentage of $C$. erectus cuttings was significantly affected by the different rooting media, cutting types, IBA concentrations and their interactions during both seasons. Among all the substrates used, vermiculite treatment showed the highest rooting percentage ( $50.7 \%$ as average of both seasons), followed by peat + perlite $(34.3 \%)$ and peat + sand (30.6\%), while the lowest rooting percentage (22.7\%) was recorded in clay medium. The increase was $123.3 \%$ in vermiculite, $51.1 \%$ in peat moss + perlite and $34.8 \%$ in peat moss + sand substrates over clay medium (Table 2).

These results are in accordance with those obtained by Rajkumar et al. (2016), Manila et al. (2017) and Peña-Baracaldo et al. (2018), who observed that vermiculite substrate was the best rooting medium in increasing the rooting percentage of many species cuttings than the other substrates. The main reasons in increasing the rooting percentage of $C$. erectus cuttings under vermiculite medium may be due to better aeration, excellent drainage, more water holding capacity and release of nutrients gradually from vermiculite medium resulting in better rooting percentages (Ansari, 2013; Manila et al., 2017). According to Wild and Jones (1992), vermiculite can adsorb phosphate forms available to the plant, which is a beneficial factor because phosphates are constituents of nucleic acids and phospholipids as well as being essential for cell division and development of meristematic tissues. In addition, the present study clears also that the addition of perlite or sand as a mineral component into peat moss substrate in proportions $1: 1$ by volume considerably improved the rootability of different types of $C$. erectus cuttings 
Table 2. Effect of rooting media, cutting types and indole-3-butyric acid (IBA) concentrations on rooting percentage, root number and root length $(\mathrm{cm})$ of Conocarpus erectus cuttings during the 2016 and 2017 seasons.

\begin{tabular}{lcccccc}
\hline \multicolumn{1}{c}{ Treatments } & \multicolumn{3}{c}{ First season (2016) } & \multicolumn{3}{c}{ Second season (2017) } \\
& Rooting\% & Root No. & Root length & Rooting\% & Root No. & Root length \\
\hline Rooting media: & & & & & & \\
Clay & 23.1 & 6.0 & 5.2 & 22.2 & 6.1 & 5.6 \\
Peat + sand & 31.7 & 7.9 & 8.4 & 29.4 & 8.2 & 9.0 \\
Peat + perlite & 36.4 & 9.4 & 9.3 & 32.2 & 9.7 & 9.8 \\
Vermiculite & 50.6 & 13.1 & 11.8 & 50.8 & 13.4 & 12.7 \\
L.S.D. at 5\% & 4.3 & 0.3 & 0.2 & 1.2 & 0.5 & 0.3 \\
Cutting types: & & & & & & \\
Tip & 67.9 & 14.0 & 13.4 & 62.1 & 14.6 & 14.2 \\
Middle & 26.3 & 8.1 & 7.6 & 24.8 & 7.9 & 8.3 \\
Basal & 12.1 & 5.2 & 5.0 & 14.2 & 5.6 & 5.2 \\
L.S.D. at 5\% & 1.7 & 0.3 & 0.2 & 1.8 & 0.3 & 0.3 \\
IBA concentrations (ppm): & & & & & \\
Control & 23.1 & 4.9 & 6.6 & 23.1 & 4.6 & 6.9 \\
50 & 38.1 & 9.8 & 8.7 & 34.4 & 10.3 & 9.5 \\
100 & 43.3 & 12.3 & 10.8 & 42.5 & 12.4 & 11.3 \\
200 & 37.2 & 9.3 & 8.6 & 34.7 & 10.2 & 9.1 \\
L.S.D. at 5\% & 1.9 & 0.1 & 0.2 & 2.0 & 0.3 & 0.3 \\
\hline
\end{tabular}

comparing with clay medium. Similar results were obtained by Tsipouridis et al. (2005), Exadaktylou et al. (2009) and Jaleta and Sulaiman (2019), who reported that combination of peat with perlite or peat with sand is suitable for rooting cuttings of some plants. The increment of rooting percentage of $C$. erectus cuttings as a result of peat + perlite and peat + sand treatments may be associated to better soil aeration and appropriate moisture holding of these media resulting in better rooting percentages (Ercişli et al., 2002). Sand is a natural and mostly used rooting medium for the most of the vegetative propagated plants. Possessing different physical and chemical properties it is when mixed with other media effectively improves the rooting (Wei et al., 2017). On the other hand, the reduction in rooting percentage with clay medium may be due to high water holding capacity leading to low aeration in the soil (Landis, 1995). Stem cuttings are sensitive to oxygen deficiency and go to rotting immediately. If the propagation media is highly humid, rooting process is delayed as a result of oxygen deficiency (Erstad and Gislerod, 1994). According to Yeboah and Amoah (2009), high aeration in propagation media is responsible for promoting metabolic activities and improving adventitious root formation.

Concerning the effect of cutting type (Table 2), it was obvious that the tip cutting recorded significantly maximum rooting percentage $(65.0 \%)$, followed by middle cutting (25.6\%), while the minimum rooting percentage was recorded in basal cuttings (13.2\%). The increments were $153.9 \%$ and $392.4 \%$ in tip cuttings over middle and basal ones, respectively. Similar results were obtained by Mohamed et al. (2014), AlDulaimy (2016) and Abdel-Rahman et al. (2020) on Conocarpus spp., who revealed that rooting percentage of the tip cuttings was better than those taken from the middle and basal portion of the branch. The difference in rooting percentage of tip, middle and basal cuttings may be attributed to higher concentration of endogenous root promoting substances in the tip cutting 
Table 3. Combined effect of rooting media, cutting types and indole-3-butyric acid (IBA) concentrations on rooting percentage, root number and root length $(\mathrm{cm})$ of Conocarpus erectus cuttings during the 2016 and 2017 seasons.

\begin{tabular}{|c|c|c|c|c|c|c|c|c|}
\hline \multirow{2}{*}{$\begin{array}{c}\text { Rooting } \\
\text { media }\end{array}$} & \multirow{2}{*}{$\begin{array}{c}\text { Cutting } \\
\text { types }\end{array}$} & \multirow{2}{*}{$\begin{array}{c}\text { IBA Con. } \\
\text { "ppm" }\end{array}$} & \multicolumn{3}{|c|}{ First season (2016) } & \multicolumn{3}{|c|}{ Second season (2017) } \\
\hline & & & Rooting\% & Root No. & Root length & Rooting\% & Root No. & Root length \\
\hline \multirow{13}{*}{ Clay } & \multirow{4}{*}{ Tip } & Control & 36.7 & 2.8 & 6.2 & 33.3 & 3.0 & 7.9 \\
\hline & & 50 & 50.0 & 11.5 & 10.0 & 46.7 & 12.2 & 11.3 \\
\hline & & 100 & 63.3 & 15.3 & 13.0 & 60.0 & 14.7 & 12.8 \\
\hline & & 200 & 56.7 & 10.4 & 10.3 & 50.0 & 10.0 & 10.1 \\
\hline & \multirow{4}{*}{ Middle } & Control & 6.7 & 1.7 & 1.7 & 6.7 & 1.5 & 1.7 \\
\hline & & 50 & 16.7 & 4.9 & 3.2 & 20.0 & 4.5 & 3.2 \\
\hline & & 100 & 16.7 & 7.2 & 5.7 & 20.0 & 7.5 & 7.2 \\
\hline & & 200 & 13.3 & 4.5 & 2.9 & 6.7 & 6.3 & 3.0 \\
\hline & \multirow{5}{*}{ Basal } & Control & 3.3 & 1.3 & 1.3 & 3.3 & 1.1 & 1.4 \\
\hline & & 50 & 6.7 & 3.3 & 2.5 & 6.7 & 3.7 & 2.5 \\
\hline & & 100 & 3.3 & 4.5 & 3.3 & 6.7 & 5.0 & 3.5 \\
\hline & & 200 & 3.3 & 3.9 & 2.2 & 6.7 & 4.1 & 2.4 \\
\hline & & Control & 50.0 & 5.8 & 10.2 & 40.0 & 6.3 & 11.4 \\
\hline \multirow{10}{*}{ Peat + sand } & \multirow{4}{*}{ Tip } & 50 & 70.0 & 14.3 & 12.8 & 60.0 & 14.3 & 14.2 \\
\hline & & 100 & 80.0 & 16.7 & 15.3 & 70.0 & 17.3 & 16.0 \\
\hline & & 200 & 66.7 & 13.5 & 12.2 & 63.3 & 14.6 & 13.8 \\
\hline & & Control & 6.7 & 2.6 & 3.3 & 10.0 & 1.9 & 3.3 \\
\hline & \multirow{4}{*}{ Middle } & 50 & 26.7 & 7.9 & 9.3 & 20.0 & 7.8 & 10.7 \\
\hline & & 100 & 30.0 & 10.1 & 10.3 & 26.7 & 9.4 & 10.7 \\
\hline & & 200 & 23.3 & 8.5 & 8.3 & 23.3 & 8.7 & 7.7 \\
\hline & & Control & 3.3 & 1.7 & 2.7 & 6.7 & 1.7 & 3.3 \\
\hline & \multirow{4}{*}{ Basal } & 50 & 10.0 & 4.7 & 4.2 & 10.0 & 5.3 & 4.5 \\
\hline & & 100 & 6.7 & 5.2 & 6.7 & 13.3 & 6.0 & 6.3 \\
\hline \multirow{13}{*}{ Peat + Perlite } & & 200 & 6.7 & 4.3 & 5.2 & 10.0 & 5.0 & 6.0 \\
\hline & & Control & 56.7 & 8.4 & 14.0 & 50.0 & 7.8 & 14.8 \\
\hline & \multirow{3}{*}{ Tip } & 50 & 80.0 & 15.5 & 15.0 & 70.0 & 16.9 & 15.3 \\
\hline & & 100 & 80.0 & 19.0 & 16.9 & 73.3 & 19.3 & 16.7 \\
\hline & & 200 & 70.0 & 15.4 & 13.5 & 63.3 & 15.9 & 14.8 \\
\hline & \multirow{5}{*}{ Middle } & Control & 10.0 & 5.6 & 5.1 & 13.3 & 5.3 & 5.3 \\
\hline & & 50 & 26.7 & 9.3 & 6.8 & 20.0 & 9.1 & 6.3 \\
\hline & & 100 & 40.0 & 11.7 & 10.0 & 33.3 & 11.4 & 12.1 \\
\hline & & 200 & 30.0 & 8.3 & 9.3 & 23.3 & 8.7 & 11.2 \\
\hline & & Control & 6.7 & 3.9 & 3.8 & 6.7 & 4.0 & 4.5 \\
\hline & \multirow{4}{*}{ Basal } & 50 & 10.0 & 5.0 & 5.3 & 6.7 & 5.5 & 5.7 \\
\hline & & 100 & 16.7 & 5.7 & 6.2 & 16.7 & 6.6 & 5.8 \\
\hline & & 200 & 10.0 & 5.1 & 5.6 & 10.0 & 6.0 & 5.0 \\
\hline \multirow{12}{*}{ Vermiculite } & & Control & 63.3 & 12.4 & 14.7 & 60.0 & 11.0 & 13.4 \\
\hline & \multirow{3}{*}{ Tip } & 50 & 80.0 & 20.3 & 16.3 & 80.0 & 22.2 & 17.7 \\
\hline & & 100 & 96.7 & 24.7 & 19.2 & 93.3 & 26.1 & 20.3 \\
\hline & & 200 & 86.7 & 17.2 & 15.3 & 80.0 & 21.3 & 17.1 \\
\hline & & Control & 20.0 & 7.3 & 11.3 & 26.7 & 6.0 & 11.7 \\
\hline & & 50 & 46.7 & 12.1 & 10.2 & 40.0 & 11.3 & 12.3 \\
\hline & Ivinare & 100 & 56.7 & 16.7 & 12.2 & 56.7 & 14.8 & 14.0 \\
\hline & & 200 & 50.0 & 11.8 & 11.5 & 50.0 & 12.4 & 12.3 \\
\hline & & Control & 13.3 & 5.7 & 4.7 & 20.0 & 5.4 & 4.7 \\
\hline & & 50 & 33.3 & 8.5 & 9.0 & 33.3 & 10.8 & 10.9 \\
\hline & Basal & 100 & 30.0 & 11.4 & 10.6 & 40.0 & 10.8 & 10.7 \\
\hline & & 200 & 30.0 & 8.6 & 7.1 & 30.0 & 9.3 & 6.7 \\
\hline L.S.D. at 5\% & & & 6.7 & 0.8 & 0.8 & 6.8 & 1.0 & 1.0 \\
\hline
\end{tabular}


tissues and also more cell which are capable of becoming meristematic (Hartmann et al., 2014; Abdel-Rahman et al., 2020). On the other hand, the low rooting percentage of basal cuttings may be due to higher lignification rate of the basal cutting tissues which can represent a mechanical barrier for root emergence (Trobec et al., 2005).

As shown in Table (2), it was noticed that all IBA concentrations used significantly increased rooting percentage of $C$. erectus cuttings compared to untreated cuttings. Treating cuttings with IBA at 100 ppm recorded significantly higher rooting percentage (42.9\%), followed by $50 \mathrm{ppm}$ IBA (36.3\%) which was not significantly different from 200 ppm IBA (36.0\%). However, the lowest percentage of rooting (23.1\%) was recorded with untreated-IBA cuttings. The increments in rooting percentage were $85.7,57.1$ and $55.8 \%$ with 100, 50 and 200 ppm IBA over the untreated-IBA treatment. These results are in agreement with the findings of Elgalby et al. (2011), AL-Tohaty et al. (2014) and Mohamed et al. (2014), who indicated that IBA concentration plays a crucial role in rooting, quality and growth of Conocarpus spp. cuttings. The increment in rooting percentage of $C$. erectus stem cuttings treated with different concentrations of IBA, especially at $100 \mathrm{ppm}$ could be due to the effect of auxins in enhancing the root ability of stem cuttings through their ability to promote the initiation of root primordia and to enhance the translocation of carbohydrates, rooting co-factors and nitrogenous substances from leaves to the base of cuttings for enhancing adventitious root formation (Rajkumar et al., 2016). Besides, auxins help in elongation of meristematic cells and differentiation of cambial initial into root primordial (Nanda, 1975). It also accelerates the translocation of nutrients from upper part of the cuttings to their basal ends by increasing the activity of enzymes. This increases hydrolysis of carbohydrates for providing enough energy for rooting response of the cells (Arya et al., 1994). As reported by Rolston et al. (1996), treating cuttings with auxin increased number of root primordia which led to increase the rooting percentage. Loach (1996) also stated that IBA treatment stimulates cell division and increased uniformity of rooting. The promoting effect of IBA on rooting is because of its conversion to IAA in plant tissue (Kumar et al., 2019). Besides, IBA may synergistically modify the action of IAA or the endogenous synthesis of IAA; IBA can enhance tissue sensitivity for IAA and increase rooting (Babaie et al., 2014). The exogenous auxins application lower the IAA oxidation and this might reduce the consumption of phenolic antioxidants, which play a very important role as protectors of the IAA against oxidation (de Klerk et al., 1999). Although IBA is one of the most effective compounds stimulating rooting in many species (Hartmann et al., 2014), its effect can vary depends on the cutting types and the concentration used (Mohamed et al., 2014). According to Leakey et al. (1982), auxins application at suitable concentration is very crucial for successful rooting of cuttings. High concentrations of auxin can cause degradation of the basal tissues of cuttings, interference in hormonal balance in plant, damage to the cells, reduction of rooting and inhibition of buds growth and even shoot development (Blythe et al., 2004). The reduction in rooting percentage at higher IBA concentrations is also a clear indication that some auxin concentrations are inhibitory to root initiation in a number of other plant species (Leakey et al., 1990). Akwatulira et al. (2011) stated that IBA at 8000 ppm was optimum in Warburgia ugandensis cuttings, while the same concentration was inhibitory in Ulmus panifolia cuttings (Griffin and Schroeder, 2004).

The interaction effect among different rooting media, cutting types and IBA concentrations on rooting percentage of $C$. erectus cuttings was significant in both seasons (Table 3). The highest rooting percentage (95.0\%) was achieved by tip cuttings treated with 100 ppm IBA and planted in vermiculite substrate, followed by 
peat + perlite $(76.7 \%)$, peat + sand $(75.0 \%)$ and clay medium (61.7\%), with the same cutting type and IBA concentration. Meanwhile, the minimum rooting percentages (6.7 and 3.3\%) were obtained from untreated-IBA middle and basal cuttings with clay medium, respectively.

The combined treatment of 100 ppm IBA with vermiculite substrate significantly improved the rooting percentage of middle (56.7\%) and basal cuttings (35.0\%) compared to the same cutting types combined with the other rooting media and IBA concentrations. Similar results were reported by Hosseini et al. (2004), Rajkumar et al. (2017) and Shiri et al. (2019), they revealed that vermiculite was the best substrate for rooting cuttings, especially when combined with a suitable concentration of IBA. Padekar et al. (2018) revealed that the days required for sprouting, rooting and survival percentages of Momordica dioica cuttings were found to be significantly influenced by the rooting media, cutting types and different IBA concentrations. The combined treatment of tip cuttings treated with 1000 ppm IBA combined with soil + sand + FYM medium recorded significantly minimum number of days required for sprouting, the highest rooting and survival percentages as compared with the remaining treatment combinations.

\section{Root and vegetative characteristics:}

The obtained results in Tables $(2,3,4$ and 5) indicate that rooting media and IBA concentrations considerably affected root and vegetative measurements in all cutting types of $C$. erectus in both seasons. It is evident from data that vermiculite substrate significantly improved the root number, root length, stem length, branch number and leaf number per rooted cutting compared to the other rooting media (Tables 2 and 4). However, the lowest root and vegetative characteristics were recorded with clay medium. Several investigations have shown that the use of vermiculite as rooting media resulted in a considerable increase in root and vegetative characteristics of cuttings

Table 4. Effect of rooting media, cutting types and indole-3-butyric acid (IBA) concentrations on stem length $(\mathrm{cm})$, branch number and leaf number of Conocarpus erectus during the 2016 and 2017 seasons.

\begin{tabular}{lcccccc}
\hline \multicolumn{1}{c}{ Treatments } & \multicolumn{3}{c}{ First season (2016) } & \multicolumn{3}{c}{ Second season (2017) } \\
& Stem length & Branch No. & Leaf No. & Stem length & Branch No. & Leaf No. \\
\hline Rooting media: & & & & & & \\
$\quad$ Clay & 21.10 & 1.10 & 7.10 & 21.20 & 1.11 & 7.30 \\
Peat + sand & 21.30 & 1.13 & 10.10 & 22.00 & 1.18 & 10.90 \\
Peat + Perlite & 23.50 & 1.53 & 11.00 & 23.20 & 1.50 & 11.80 \\
Vermiculite & 25.50 & 1.80 & 13.50 & 25.80 & 1.86 & 14.10 \\
L.S.D. at 5\% & 0.30 & 0.02 & 0.30 & 0.30 & 0.09 & 0.30 \\
Cutting types: & & & & & & \\
$\quad$ Tip & 25.30 & 1.59 & 12.80 & 25.60 & 1.61 & 13.40 \\
Middle & 22.20 & 1.34 & 10.10 & 22.50 & 1.35 & 10.80 \\
Basal & 20.90 & 1.24 & 8.30 & 21.00 & 1.27 & 8.90 \\
L.S.D. at 5\% & 0.20 & 0.02 & 0.30 & 0.40 & 0.03 & 0.30 \\
IBA concentrations (ppm): & & & & & & \\
Control & 20.60 & 1.14 & 8.40 & 20.80 & 1.18 & 9.00 \\
50 & 23.10 & 1.36 & 10.60 & 23.30 & 1.37 & 11.20 \\
100 & 25.00 & 1.70 & 12.90 & 25.20 & 1.74 & 13.70 \\
200 & 22.60 & 1.37 & 9.90 & 22.90 & 1.35 & 10.30 \\
L.S.D. at 5\% & 0.30 & 0.02 & 0.20 & 0.30 & 0.04 & 0.30 \\
\hline
\end{tabular}


Table 5. Combined effect of rooting media, cutting types and indole-3-butyric acid (IBA) concentrations on stem length $(\mathrm{cm})$, branch number and leaf number of Conocarpus erectus during the 2016 and 2017 seasons.

\begin{tabular}{|c|c|c|c|c|c|c|c|c|}
\hline \multirow{2}{*}{$\begin{array}{c}\text { Rooting } \\
\text { media }\end{array}$} & \multirow{2}{*}{$\begin{array}{c}\text { Cutting } \\
\text { types }\end{array}$} & \multirow{2}{*}{$\begin{array}{l}\text { IBA Con. } \\
\text { "ppm" }\end{array}$} & \multicolumn{3}{|c|}{ First season $(2016)$} & \multicolumn{3}{|c|}{ Second season $(2017)$} \\
\hline & & & Stem length & Branch No. & Leaf No. & Stem length & Branch No. & Leaf No. \\
\hline \multirow{13}{*}{ Clay } & \multirow{4}{*}{ Tip } & Control & 19.30 & 1.03 & 6.40 & 20.20 & 1.07 & 6.70 \\
\hline & & 50 & 24.10 & 1.13 & 9.70 & 23.50 & 1.20 & 8.70 \\
\hline & & 100 & 26.60 & 1.28 & 11.10 & 26.40 & 1.29 & 11.50 \\
\hline & & 200 & 23.70 & 1.10 & 9.10 & 23.70 & 1.13 & 9.80 \\
\hline & \multirow{4}{*}{ Middle } & Control & 18.60 & 1.07 & 4.20 & 18.80 & 1.03 & 4.30 \\
\hline & & 50 & 20.30 & 1.10 & 7.00 & 20.30 & 1.03 & 6.90 \\
\hline & & 100 & 22.70 & 1.20 & 9.00 & 21.30 & 1.22 & 9.60 \\
\hline & & 200 & 21.50 & 1.07 & 7.00 & 21.80 & 1.07 & 7.60 \\
\hline & \multirow{4}{*}{ Basal } & Control & 17.40 & 1.00 & 3.30 & 17.70 & 1.00 & 3.50 \\
\hline & & 50 & 18.20 & 1.00 & 5.80 & 18.90 & 1.03 & 5.80 \\
\hline & & 100 & 20.50 & 1.13 & 7.20 & 21.00 & 1.16 & 7.50 \\
\hline & & 200 & 20.00 & 1.03 & 5.40 & 20.70 & 1.07 & 5.60 \\
\hline & \multirow{4}{*}{ Tip } & Control & 21.20 & 1.19 & 10.70 & 21.90 & 1.66 & 12.00 \\
\hline \multirow{10}{*}{ Peat + sand } & & 50 & 23.30 & 1.18 & 12.50 & 25.00 & 1.19 & 13.30 \\
\hline & & 100 & 26.90 & 1.27 & 15.50 & 27.30 & 1.29 & 16.00 \\
\hline & & 200 & 22.60 & 1.17 & 12.10 & 23.60 & 1.18 & 12.90 \\
\hline & \multirow{4}{*}{ Middle } & Control & 18.30 & 1.08 & 8.40 & 18.90 & 1.03 & 9.10 \\
\hline & & 50 & 20.30 & 1.09 & 9.00 & 21.60 & 1.10 & 10.70 \\
\hline & & 100 & 22.60 & 1.20 & 11.50 & 24.00 & 1.23 & 12.40 \\
\hline & & 200 & 21.60 & 1.11 & 10.00 & 22.70 & 1.15 & 9.80 \\
\hline & \multirow{4}{*}{ Basal } & Control & 17.70 & 1.00 & 6.90 & 17.70 & 1.00 & 7.10 \\
\hline & & 50 & 20.10 & 1.06 & 7.40 & 19.90 & 1.06 & 9.10 \\
\hline & & 100 & 21.00 & 1.13 & 9.70 & 21.20 & 1.18 & 10.60 \\
\hline \multirow{14}{*}{ Peat + perlite } & & 200 & 20.00 & 1.04 & 7.00 & 19.80 & 1.07 & 7.60 \\
\hline & \multirow{4}{*}{ Tip } & Control & 23.30 & 1.22 & 11.80 & 23.70 & 1.23 & 12.60 \\
\hline & & 50 & 25.70 & 1.55 & 13.60 & 24.90 & 1.50 & 14.00 \\
\hline & & 100 & 28.40 & 2.70 & 16.20 & 27.90 & 2.62 & 17.00 \\
\hline & & 200 & 25.00 & 1.77 & 12.00 & 24.60 & 1.53 & 12.90 \\
\hline & \multirow{5}{*}{ Middle } & Control & 21.70 & 1.10 & 8.90 & 22.00 & 1.15 & 11.10 \\
\hline & & 50 & 23.30 & 1.30 & 11.00 & 23.10 & 1.37 & 11.90 \\
\hline & & 100 & 24.00 & 1.90 & 12.60 & 23.30 & 1.85 & 14.30 \\
\hline & & 200 & 22.50 & 1.50 & 10.00 & 22.10 & 1.33 & 10.30 \\
\hline & & Control & 21.00 & 1.02 & 7.70 & 21.20 & 1.02 & 8.10 \\
\hline & \multirow{3}{*}{ Basal } & 50 & 22.50 & 1.30 & 9.40 & 22.50 & 1.28 & 9.70 \\
\hline & & 100 & 23.30 & 1.70 & 10.30 & 22.30 & 1.70 & 10.70 \\
\hline & & 200 & 21.00 & 1.33 & 8.60 & 21.00 & 1.36 & 9.10 \\
\hline & \multirow{4}{*}{ Tip } & Control & 24.60 & 1.40 & 12.80 & 24.30 & 1.37 & 12.80 \\
\hline \multirow{11}{*}{ Vermiculite } & & 50 & 29.20 & 2.40 & 16.60 & 29.70 & 2.47 & 17.30 \\
\hline & & 100 & 33.50 & 2.90 & 21.00 & 36.20 & 2.86 & 22.10 \\
\hline & & 200 & 27.60 & 2.20 & 14.10 & 27.10 & 2.10 & 15.00 \\
\hline & & Control & 22.30 & 1.30 & 10.20 & 22.60 & 1.37 & 11.00 \\
\hline & Middle & 50 & 26.10 & 1.70 & 13.70 & 26.00 & 1.70 & 14.30 \\
\hline & Midde & 100 & 26.50 & 2.10 & 17.00 & 26.50 & 2.37 & 18.50 \\
\hline & & 200 & 23.50 & 1.60 & 12.10 & 24.50 & 1.67 & 11.50 \\
\hline & & Control & 21.40 & 1.23 & 9.10 & 20.70 & 1.20 & 9.60 \\
\hline & Basal & 50 & 23.60 & 1.47 & 11.10 & 23.90 & 1.50 & 12.30 \\
\hline & DasdI & 100 & 24.70 & 1.93 & 13.30 & 24.60 & 2.17 & 14.10 \\
\hline & & 200 & 22.50 & 1.47 & 10.90 & 23.50 & 1.50 & 11.30 \\
\hline L.S.D. at 5\% & & & 1.20 & 0.08 & 0.80 & 1.10 & 0.15 & 0.90 \\
\hline
\end{tabular}




\section{S.S.A. Abdel-Rahman}

comparing with the other substrates (Ansari, 2013; Manila et al., 2017; Peña-Baracaldo et al., 2018). The positive effect of vermiculite substrate in increasing the root and shoot characteristics of cuttings may be attributed to its role on improving the soil aeration resulting in high water retention capacity and more availability of nutrients to roots (Rajkumar et al., 2017; Kumar et al., 2019). Besides, the highest stem length, branch number and leaf number recorded from vermiculite substrate may be attributed to easy translocation of water and nutrients to the above ground parts of the cuttings, leading to their rapid growth and multiplication (Akwatulira et al., 2011; Dawa et al., 2018). According to Grange and Loach (1983), water uptake by cuttings is indirectly proportional to the water content of the medium, as determined by its water retention and aeration properties (Kumar et al., 2019). The increase in water uptake could be attributed to increase auxin uptake (Ercişli et al., 2002). On the other hand, the present results revealed that the cuttings planted in peat + perlite or peat + sand substrates showed better root and shoot performance than clay soil. These results may be attributed to that these substrates allow air to reach the newly forming roots and also holds enough water to prevent the lower end of the cuttings from drying (Dawa et al., 2018). The combination of peat and perlite in a rooting substrate is synergistic; peat often improves the fertilizing capacity of a substrate and perlite enhances aeration and drainage within the container because of its uniformity and lightness (Al-Makhmari, 2016). Sand is a natural and mostly used rooting medium for the most of the vegetative propagation in plants. Possessing different physical and chemical properties it is when mixed with other media effectively improves the vegetative growth parameters of carnation plant (Wei et al., 2017). The reduction in root and shoot parameters of $C$. erectus cuttings in clay medium could be due to very low aeration and porosity which can lead to rotting of the cuttings (Amri et al., 2009).
Concerning the effect of cutting types, it is evident from the obtained data in Tables (2 and 4) that the tip recorded the highest root number and root length per rooted cutting, which reflected in improving the vegetative growth characteristics in terms of stem length, branch number and leaf number compared to the middle and basal ones during both seasons. Similar results were also obtained by Mohamed et al. (2014), AlDulaimy (2016) and Abdel-Rahman et al. (2020), who indicated that propagation of Conocarpus spp. by tip cuttings significantly improved the root and shoot parameters comparing with middle and basal ones. Besides, Padekar et al. (2018) revealed also that using the tip cutting in propagation of Momordica dioica resulted in the best root and shoot characteristics of rooted cuttings compared to middle and basal ones. The increment in root and vegetative characteristics of $C$. erectus tip cuttings may be due to high content of endogenous rootpromoting substances in the tip cutting tissues and the anatomical structure of the stem (Hansen, 1986).

As illustrated in Tables (2 and 4), it is clearly shown that the root and vegetative growth characteristics of $C$. erectus rooted cuttings were found to be markedly influenced by the different IBA concentrations in both seasons. All IBA concentrations used significantly enhanced all root and vegetative parameters when compared to untreated cuttings. Application of IBA at 100 ppm gave strong effects on root number and root length, stem length, branch number and leaf number per rooted cutting of $C$. erectus compared to the other concentrations used. The concentration of 50 ppm IBA was close to 200 ppm IBA in increasing both root and vegetative parameters compared to untreated control. These results indicated that IBA concentration of $50 \mathrm{ppm}$ was low and 200 ppm was high for enhancing the root and growth characteristics of $C$. erectus cuttings. Similar results were also reported by AlDulaimy (2016) and Abdel-Rahman et al. (2020) on Conocarpus erectus, they 
indicated that the exogenous IBA application significantly improved root and vegetative parameters of rooted cuttings compared to untreated cuttings. They also added that IBA concentrations may be important for the root and growth performance of cuttings in many plants. Exogenous application of auxin may have caused hydrolysis and translocation of carbohydrate and nitrogenous substances present at the base of cuttings, which resulted in an increase in the root characteristics (Singh et al., 2003). Application of IBA at optimum concentration increases the rate of amyloplast disappearance, amyloplast levels decrease naturally during rooting process (Singh et al., 2014). Gilani et al. (2019) showed that at optimum IBA, the reduction of amyloplast can be increased and cambium activities are stimulated, that will mobilize stored food material to the root initiation zones, hence promoting adventitious root formation. This trend is in line with the findings of Mohamed (2005) on Vitis vinifera, who reported that the lower concentration of IBA (5000 ppm IBA) gave the highest number and length of roots compared with the higher concentration (6000 ppm IBA) used on middle cuttings. Induction of more roots in treated cuttings with IBA may be due to the fact that cambial activity involved in root initiation is stimulated by exogenous IBA application in many species (Hartmann et al., 2014). On the other hand, the increment in root length as a result of IBA application may be attributed to the fact that proteins from IBA break hydrogen bonds between cellulose micro fibrils promoting cell wall loosening and cells will eventually elongate (Kumar et al., 2015). At suitable concentration of IBA, the rate of cambium dedifferentiation is increased, accelerated hydrolytic activity leading to produce better root length (Gilani et al., 2019). Besides, IBA promotes root length by influencing the synthesis of enzymes which stimulate cell enlargement (Rajkumar et al., 2017). Moreover, the increase in root parameters of C. erectus rooted cuttings may be due to higher accumulation of photosynthetic, metabolites and nutrients with IBA application (Rajkumar et al., 2016). Besides, Padekar et al. (2018) postulated also that the increment in root and growth measurements in cuttings treated with IBA might be due to its effect on cell wall elasticity, which accelerates cell division and stimulates root growth. On the other hand, the increment in vegetative growth characteristics might be associated with the increased number and length of roots in treated cuttings that enhances uptake of water and nutrients from the rooting media and hence more vegetative growth (Dawa et al., 2018). Roots system is significantly involved in plant growth due to their role in water and nutrient uptake, therefore maintaining an active roots growth is essential for plant development (Hartmann et al., 2014).

Statistical analysis of the obtained results in this study (Tables 3 and 5) revealed that the root and vegetative characteristics of $C$. erectus cuttings were significantly influenced by the interaction among rooting media, cutting type and IBA concentrations during both seasons. Generally, treating tip cuttings with IBA at $100 \mathrm{ppm}$ gave better root and growth parameters of cuttings than untreated-IBA cuttings in all rooting media used. The best combined treatment of tip cuttings treated with 100 ppm IBA and planted in vermiculite substrate which recorded the highest rooting percentage produced the highest root number and root length which positively reflected on better vegetative characteristics in terms of stem length, shoot number and leaf number per rooted cutting, followed by peat + perlite and peat + sand, respectively with the same cutting type and IBA concentration. Meanwhile the lowest root and vegetative characteristics were recorded with untreatedIBA middle and basal cuttings and planted in clay medium. In addition, the combined treatment of $100 \mathrm{ppm}$ IBA and vermiculite substrate could significantly improve all root and vegetative growth characteristics studied of middle and basal cuttings compared to the same cutting types combined with the other 


\section{S.S.A. Abdel-Rahman}

rooting media and IBA concentrations. These results are in close conformity with the findings of Rajkumar et al. (2017) and Padekar et al. (2018), who observed that the root and vegetative parameters of rooted cuttings were greatly influenced by the rooting media, cutting type and IBA concentration. Rajkumar et al. (2016) stated that the maximum root and vegetative growth characteristics of Punica granatum cuttings were recorded with cuttings treated with 2500 ppm IBA with vermiculite substrate.

Some studies have shown that treatment of tip cuttings of Conocarpus spp. with IBA led to increase the root, shoot characteristics as compared to the untreated-IBA middle and basal cuttings (Al-Dulaimy, 2016; Abdel-Ramann et al., 2020). The reason in increasing the root and vegetative growth characteristics of $C$. erectus tip cuttings treated with IBA compared to untreated-IBA middle and basal cuttings may be attributed to higher endogenous IAA content in tip cutting tissues (Wróblewska, 2015). This stimulated cell division which resulted in the root primordia formation to absorb water and nutrients from the medium for early root growth and subsequent vegetative growth (Hartmann et al., 2014). Besides, the high water holding capacity and good aeration of the vermiculite media, peat + perlite and peat + sand were efficiently utilized by the stem cuttings in combination with available nutrients from the rooting media for shoot growth (Kumar et al., 2019). Sand with coir dust (1:1) medium with 150 ppm NAA was best for root growth performances in soft wood cuttings of Chirita moonii (Rubasinghe et al., 2009).

\section{$\mathrm{C} / \mathrm{N}$ ratio and total phenols content:}

As shown in Tables (6 and 7), $\mathrm{C} / \mathrm{N}$ ratio and total phenols content in basal part of $C$. erectus cuttings were significantly influenced by different rooting media, cutting types and IBA concentrations in both seasons. Among the rooting media, the highest $\mathrm{C} / \mathrm{N}$ ratio and total phenols content in cutting tissues were recorded under vermiculite medium which led to best rooting and growth of cuttings, followed by peat + perlite and peat + sand, respectively while the lowest values were recorded with

Table 6. Effect of rooting media, cutting types and indole-3-butyric acid (IBA) concentrations on $\mathrm{C} / \mathrm{N}$ ratio and total phenols content (mg GAE/g dry weight) in cutting tissues of Conocarpus erectus during the 2016 and 2017 seasons.

\begin{tabular}{lcccc}
\hline \multicolumn{1}{c}{ Treatments } & \multicolumn{2}{c}{ First season (2016) } & \multicolumn{2}{c}{ Second season (2017) } \\
C/N ratio & Total phenols & C/N ratio & Total phenols \\
\hline Rooting media: & & & & \\
Clay & 10.2 & 33.3 & 10.4 & 35.0 \\
Peat + sand & 12.4 & 41.4 & 11.7 & 43.3 \\
Peat + Perlite & 14.8 & 44.7 & 13.5 & 46.3 \\
Vermiculite & 16.6 & 46.9 & 15.4 & 47.9 \\
L.S.D. at 5\% & 0.3 & 1.0 & 0.2 & 0.7 \\
Cutting types: & & & & \\
Tip & 11.7 & 51.0 & 10.5 & 52.4 \\
Middle & 13.6 & 40.5 & 12.7 & 41.8 \\
Basal & 15.3 & 33.2 & 15.0 & 35.2 \\
L.S.D. at 5\% & 0.2 & 0.9 & 0.3 & 0.7 \\
IBA concentrations (ppm): & & & & \\
Control & 11.4 & 33.4 & 10.5 & 34.9 \\
50 & 13.4 & 43.8 & 13.0 & 45.7 \\
100 & 16.1 & 48.3 & 15.0 & 49.6 \\
200 & 13.2 & 40.7 & 12.5 & 42.4 \\
L.S.D. at 5\% & 0.2 & 0.7 & 0.1 & 0.7 \\
\hline
\end{tabular}


Table 7. Combined effect of rooting media, cutting types and indole-3-butyric acid (IBA) concentrations on $\mathrm{C} / \mathrm{N}$ ratio and total phenols content (mg GAE/g dry weight) in cutting tissues of Conocarpus erectus during the 2016 and 2017 seasons.

\begin{tabular}{|c|c|c|c|c|c|c|}
\hline \multirow{2}{*}{$\begin{array}{l}\text { Rooting } \\
\text { media }\end{array}$} & \multirow{2}{*}{$\begin{array}{c}\text { Cutting } \\
\text { types }\end{array}$} & \multirow{2}{*}{$\begin{array}{c}\text { IBA Con. } \\
\text { “ppm” }\end{array}$} & \multicolumn{2}{|c|}{ First season (2016) } & \multicolumn{2}{|c|}{ Second season (2017) } \\
\hline & & & $\mathrm{C} / \mathrm{N}$ ratio & Total phenols & $\mathrm{C} / \mathrm{N}$ ratio & Total phenols \\
\hline \multirow{13}{*}{ Clay } & \multirow{4}{*}{ Tip } & Control & 6.7 & 37.9 & 6.5 & 39.4 \\
\hline & & 50 & 8.6 & 48.9 & 8.6 & 51.9 \\
\hline & & 100 & 10.6 & 54.9 & 10.4 & 54.8 \\
\hline & & 200 & 8.3 & 46.6 & 8.1 & 48.5 \\
\hline & \multirow{4}{*}{ Middle } & Control & 8.9 & 19.0 & 9.1 & 20.5 \\
\hline & & 50 & 9.8 & 31.6 & 11.0 & 33.7 \\
\hline & & 100 & 11.4 & 39.0 & 12.7 & 40.4 \\
\hline & & 200 & 10.1 & 31.0 & 10.6 & 31.7 \\
\hline & \multirow{5}{*}{ Basal } & Control & 10.9 & 14.2 & 10.2 & 15.8 \\
\hline & & 50 & 12.2 & 24.5 & 12.5 & 26.7 \\
\hline & & 100 & 14.2 & 28.3 & 14.0 & 32.1 \\
\hline & & 200 & 11.1 & 24.0 & 11.4 & 24.2 \\
\hline & & Control & 8.6 & 43.6 & 8.0 & 42.1 \\
\hline \multirow{10}{*}{ Peat + sand } & \multirow{4}{*}{ Tip } & 50 & 10.7 & 51.7 & 10.0 & 54.1 \\
\hline & & 100 & 13.3 & 58.1 & 11.2 & 57.1 \\
\hline & & 200 & 9.6 & 48.6 & 9.1 & 49.7 \\
\hline & & Control & 9.8 & 32.9 & 9.8 & 34.3 \\
\hline & \multirow{4}{*}{ Middle } & 50 & 12.9 & 44.4 & 12.5 & 46.6 \\
\hline & & 100 & 14.4 & 46.9 & 13.5 & 50.4 \\
\hline & & 200 & 12.2 & 40.0 & 12.7 & 42.9 \\
\hline & & Control & 12.0 & 23.0 & 11.8 & 29.5 \\
\hline & \multirow{4}{*}{ Basal } & 50 & 14.3 & 37.2 & 13.4 & 38.2 \\
\hline & & 100 & 15.6 & 37.8 & 15.4 & 42.4 \\
\hline \multirow{14}{*}{ Peat + Perlite } & & 200 & 14.9 & 31.9 & 13.4 & 33.0 \\
\hline & & Control & 10.2 & 41.2 & 9.1 & 42.9 \\
\hline & \multirow{4}{*}{ Tip } & 50 & 13.7 & 54.1 & 11.5 & 56.7 \\
\hline & & 100 & 15.5 & 62.6 & 14.6 & 62.8 \\
\hline & & 200 & 13.5 & 48.3 & 11.0 & 53.6 \\
\hline & & Control & 12.4 & 37.2 & 11.0 & 36.9 \\
\hline & \multirow{4}{*}{ Middle } & 50 & 14.9 & 46.1 & 13.2 & 48.0 \\
\hline & & 100 & 17.1 & 49.9 & 15.2 & 50.9 \\
\hline & & 200 & 15.1 & 43.6 & 12.7 & 43.9 \\
\hline & & Control & 13.6 & 31.8 & 12.3 & 33.7 \\
\hline & \multirow{4}{*}{ Basal } & 50 & 16.1 & 39.2 & 16.3 & 41.2 \\
\hline & & 100 & 19.5 & 46.1 & 18.8 & 45.1 \\
\hline & & 200 & 16.3 & 36.3 & 16.1 & 39.7 \\
\hline & & Control & 12.4 & 44.9 & 11.3 & 46.5 \\
\hline \multirow{11}{*}{ Vermiculite } & \multirow{4}{*}{ Tip } & 50 & 14.2 & 57.4 & 12.7 & 59.1 \\
\hline & & 100 & 17.1 & 63.9 & 14.2 & 65.7 \\
\hline & & 200 & 13.5 & 53.1 & 12.3 & 53.9 \\
\hline & & Control & 14.8 & 40.0 & 12.5 & 40.7 \\
\hline & \multirow{3}{*}{ Middle } & 50 & 15.7 & 49.7 & 15.3 & 49.7 \\
\hline & & 100 & 21.2 & 50.8 & 17.2 & 50.0 \\
\hline & & 200 & 16.1 & 46.2 & 14.7 & 47.7 \\
\hline & & Control & 16.2 & 35.0 & 14.8 & 36.1 \\
\hline & & 50 & 17.8 & 41.3 & 19.0 & 42.7 \\
\hline & Basal & 100 & 23.0 & 41.5 & 22.8 & 43.1 \\
\hline & & 200 & 17.1 & 38.4 & 18.0 & 40.0 \\
\hline L.S.D. at 5\% & & & 0.7 & 2.5 & 0.7 & 2.4 \\
\hline
\end{tabular}


clay medium with significant differences between them (Table 6). This could be due to the fact that vermiculite medium has better aeration potential and drainage which provided with good root system led to more water and nutrients uptake from rooting media resulting in better vegetative growth, higher $\mathrm{C} / \mathrm{N}$ ratio and total phenols content.

Concerning the effect of cutting types, basal cuttings contained higher $\mathrm{C} / \mathrm{N}$ ratio and lower total phenols content than tip and middle ones, while tip cuttings contained higher total phenols content and lower $\mathrm{C} / \mathrm{N}$ ratio (Table 6). It is evident from the current findings that the root ability of basal cuttings was not related to their content of $\mathrm{C} / \mathrm{N}$ ratio, while there was a positive correlation between root ability of tip cuttings and higher $\mathrm{C} / \mathrm{N}$ ratio. Similar trends were reported by Denaxa et al. (2012) and AbdelRahman et al. (2020). Abdel-Rahman and El-Naggar (2014) postulated that basal cuttings of Bougainvillea contained higher $\mathrm{C} / \mathrm{N}$ ratio than tip and middle ones. For phenols, Haissig (1974) and Abdel-Rahman et al. (2020) revealed that phenols in juvenile tissues of certain plants tend to be higher than their mature forms. More lignified tissues have additionally a higher IAAoxidase activity (Liu et al., 1998); therefore conditions were less favorable for rooting of basal cuttings, which clearly could not keep the endogenous IAA concentration on the level of satisfying rooting.

On the other hand, the obtained data in Table (6) indicate that the exogenous IBA application significantly increased $\mathrm{C} / \mathrm{N}$ ratio and total phenols content compared to untreated-IBA cuttings. The highest $\mathrm{C} / \mathrm{N}$ ratio and total phenols content were recorded with IBA at $100 \mathrm{ppm}$, followed by 50 and 200 ppm IBA, respectively with significant differences between them. Generally, the basal cuttings treated with 100 ppm IBA under vermiculite medium contained the highest $\mathrm{C} / \mathrm{N}$ ratio, while tip cuttings contained the highest total phenols content with same IBA concentration under vermiculite medium compared to the other combinations (Table 7). These results are in agreement with the findings of Mahrose (2000) and Abdel-Rahman et al. (2020), who revealed that the high rootability of cuttings was associated with high $\mathrm{C} / \mathrm{N}$ ratio and total phenols content in cutting tissues. According to Attia and Moftah (1992), treatment of Euphorbia pulcherrima cuttings with IBA considerably increased $\mathrm{C} / \mathrm{N}$ ratio and consequently enhanced the rootability of cuttings. Exogenous IBA application could have an indirect influence on rooting by increasing the speed of transformation and movement of sugars and other assimilates to the base of cuttings thereby stimulating root formation (Davies, 2004).

Several investigations have reported that treatment of cuttings with IBA resulted in an increase in total phenols content (Amin et al., 2006; Abdel-Rahman et al., 2020). Phenols act as auxin-cofactor in promotion of adventitious root formation and reduction in rootability of cuttings can be due to the reduction of phenolic compounds (KhandanMirkohi et al., 2015). The role of phenolic compounds in adventitious root formation is in protecting the rooting-inducer endogenous auxin IAA from being destructed by peroxidase, which can act as an IAA oxidase (De Klerk et al., 2011). According to Scagel and Linderman (1998), the increment in total phenols content in cutting tissues as a result of treatment of cuttings with IBA has a direct role in inhibiting auxin oxidation so more auxin is available to induce roots and enhance the root and vegetative growth characteristics of cuttings.

\section{Indole acetic acid (IAA) and Abscisic acid (ABA) contents:}

Table (8) shows HPLC analysis of samples extracted from the tip, middle and basal cuttings of $C$. erectus for the control and treated with 100 ppm IBA in clay and vermiculite medium. It is clear that IAA content in cutting tissues planted in vermiculite was higher (33.04 $\mu \mathrm{g} / \mathrm{g}$ f.w.) than in clay medium (22.64 $\mu \mathrm{g} / \mathrm{g}$ f.w.). Treating cuttings with IBA at 100 ppm showed the highest content of IAA (35.12 
Table 8. Content of indole acetic acid (IAA) and abscisic acid (ABA) at root zone of three cutting types of Conocarpus erectus L. treated with $100 \mathrm{ppm}$ IBA and the control under vermiculite and clay medium.

\begin{tabular}{|c|c|c|c|c|}
\hline \multirow{2}{*}{ Rooting media } & \multirow{2}{*}{ Cutting type } & \multicolumn{3}{|c|}{ IBA concentration (ppm) } \\
\hline & & Control & 100 & Mean \\
\hline \multirow{6}{*}{ Clay } & \multicolumn{4}{|c|}{ IAA ( $\mu g / g$ f.w.) } \\
\hline & Tip & 31.120 & 45.240 & 38.180 \\
\hline & Middle & 8.520 & 29.400 & 18.960 \\
\hline & Basal & 5.030 & 16.510 & 10.770 \\
\hline & Mean & 14.890 & 30.380 & 22.640 \\
\hline & Tip & 48.240 & 61.250 & 54.750 \\
\hline \multirow{3}{*}{ Vermiculite } & Middle & 19.240 & 37.150 & 28.200 \\
\hline & Basal & 11.210 & 21.170 & 16.190 \\
\hline & Mean & 26.230 & 39.860 & 33.040 \\
\hline \multirow[t]{2}{*}{ General mean } & & 20.560 & 35.120 & 27.840 \\
\hline & \multicolumn{4}{|c|}{ ABA ( $\mu g / g$ f.w.) } \\
\hline \multirow{4}{*}{ Clay } & Tip & 0.124 & 0.052 & 0.088 \\
\hline & Middle & 0.182 & 0.124 & 0.153 \\
\hline & Basal & 0.412 & 0.306 & 0.359 \\
\hline & Mean & 0.239 & 0.161 & 0.200 \\
\hline \multirow{4}{*}{ Vermiculite } & Tip & 0.091 & 0.028 & 0.060 \\
\hline & Middle & 0.150 & 0.103 & 0.127 \\
\hline & Basal & 0.321 & 0.264 & 0.293 \\
\hline & Mean & 0.187 & 0.132 & 0.160 \\
\hline General mean & & 0.213 & 0.146 & 0.180 \\
\hline
\end{tabular}

$\mu \mathrm{g} / \mathrm{g}$ f.w.) compared to control (20.56 $\mu \mathrm{g} / \mathrm{g}$ f.w.). The highest IAA content $(61.25 \mu \mathrm{g} / \mathrm{g}$ f.w.) was obtained from tip cuttings treated with IBA at $100 \mathrm{ppm}$ under vermiculite medium. However, the lowest IAA content (5.03 $\mu \mathrm{g} / \mathrm{g} \quad$ f.w.) was recorded with untreated-IBA basal cuttings under clay medium. The current study indicates a positive correlation between the higher endogenous IAA content and rootability of cuttings. These results are in accordance with those reported by Weigel et al. (1984) and El Botaty and Saleh (2018), who cleared that treatment of cuttings with IBA increased the endogenous IAA content led to improve the rooting and growth of cuttings comparing with untreated cuttings. Better rooting and growth of tip cuttings comparing with the middle and basal ones can be due to the presence of higher IAA and phenols levels as well as lower ABA content in tip cutting tissues, so it is possible that IAA and phenols levels decrease with increased distance from shoot tip leading to low rooting percentage (Palanisamy and Kumar, 1997).

As for ABA content, the obtained results (Table 8) show that clay medium exhibited the highest ABA content $(0.200 \mu \mathrm{g} / \mathrm{g}$ f.w. $)$, while the lowest content $(0.160 \mu \mathrm{g} / \mathrm{g}$ f.w. $)$ was recorded in vermiculite medium. Treatment of $C$. erectus cuttings with 100 ppm IBA caused a reduction in endogenous ABA content $(0.146 \mu \mathrm{g} / \mathrm{g}$ f.w.) compared to the control $(0.213 \mu \mathrm{g} / \mathrm{g}$ f.w.). The lowest endogenous ABA content $(0.028 \mu \mathrm{g} / \mathrm{g}$ f.w.) was obtained from tip cuttings treated with 100 ppm IBA under vermiculite medium, while the highest value $(0.412 \mu \mathrm{g} / \mathrm{g}$ f.w. $)$ was recoded with untreated-IBA basal cuttings under clay medium. These results are in agreement with those reported by Tilahun et al. (2019) and Abdel-Rahman et al. (2020), who stated that a low IAA and high ABA contents is correlated with low rootability of cuttings, whereas the opposite was found in high rooting rate cuttings. 


\section{REFERENCES}

Abdel-Rahman, S.S.A. and El-Naggar, A.I. (2014). Promotion of rooting and growth of some types of Bougainvilleas cutting by plant growth promoting rhizobacteria (PGPR) and arbuscular mycorrhizal fungi (AMF) in combination with indole-3butyric acid (IBA). Inter. J. Sci. Res., 3(11):97-108.

Abdel-Rahman, S.S.A.; Abdul-Hafeez, E.Y. and Saleh, A.M.M. (2020). Improving rooting and growth of Conocarpus erectus stem cuttings using indole-3butyric acid (IBA) and some biostimulants. Scientific J. Flowers and Ornamental Plants, 7(2):109-129.

Akwatulira, F.; Gwali, S.; Okullo, J.B.L.; Ssegawa, P.; Tumwebaze, S.B.; Mbwambo, J.R. and Muchugi, A. (2011). Influence of rooting media and indole-3butyric acid (IBA) concentration on rooting and shoot formation of Warburgia ugandensis stem cuttings. African J. Plant Sci., 5(8):421-429.

Al-Dulaimy, H.A. (2016). Effect of cutting types on stem and growing media on cuttings rooting and vegetative growth of Conocarpus lancifolius. Al-Kufa Univ. J. Bio., 8(1):98-103.

Al-Makhmari, S.M. (2016). Effect of Substrates, IBA and Types of Cuttings on Rooting of Tamarix aphylla L. M.Sc., Department of Aridland Agriculture, College of Food and Agriculture, United Arab Emirates University, Emirates, $80 \mathrm{p}$.

Al-Tohaty, S.A.; Lateef, A.A. and Abdelraheem, H.A. (2014). Effect of cuttings type, planting date and treatment of indole butyric acid (IBA) on rooting of cuttings and vegetative growth properties of Damas (Conocarpus lancifolius) for summer season. Alforat, J. Agric. Sci., 6(2):1-11.

Amin, A.A.; Rashad, M.E. and Gharib, F.A.E. (2006). Physiological response of maize plants (Zea mays L.) to foliar application of morphactin CF125 and indole-3-butyric acid. J. Biol. Sci., 6:547554.

Amri, E.; Lyarun, H.V.M.; Nyomora, A.S. and Kanyek, Z.L. (2009). Evaluation of provenances and rooting media for rooting ability of African blackwood (Dalbergia melanoxylon Guill. and Perr.) stem cuttings. Res. J. Agric. Biol. Sci., 5(4):524-532.

Ansari, K. (2013). Effects of different collecting time and different media on rooting of pomegranate "Malas torsh cv." cuttings. Bull. Env. Pharmacol. Life Sci., 2(12):164-168.

Arya, S.; Tomar, R. and Tokoyt, O.P. (1994). Effect of plant age and auxin treatment on rooting response in stem cuttings of Prosopis cineraria. J. Arid Environ., 27: 99-103.

Attia, F.A. and Moftah, A.E. (1992). Effect of IBA and DHT on rooting growth and chemical composition of Euphorbia pulcherrima. Mansoura J. Agric. Sci., 17(7):2412-2419.

Babaie, H.; Zarei, H.; Nikde, K. and Firoozhai, M.N. (2014). Effect of different concentrations of IBA and time of taking cutting on rooting, growth and survival of Ficus binnendijkii 'amstel queen' cuttings. Notulae Sci. Bio., 6(2):163-166.

Black, C.A.; Evans, D.D.; Nhite, J.I.; Ensminger, L.E. and Clark, F.E. (1982). Methods of Soil Analysis. J. Amer. Soc. Agron. Inc. Madison, Wisconsin U.S.A.

Blythe, E.K.; Sibley, J.L.; Ruter, J.M. and Tilt, K.M. (2004): Cutting propagation of foliage crops using a foliar application of auxin. Scientia Horticulturae, 103(1):3137.

Caldwell, J.D.; Coston, D.C. and Brock, K.H. (1988). Rooting of semi-hardwood 'Hayward' kiwifruit cuttings. HortScience, 23:714-717. 
Daskalakis, I.; Biniari, K.; Bouza, D. and Stavrakaki, M. (2018). The effect that indole butyric acid (IBA) and position of cane segment have on the rooting of cuttings from grapevine rootstocks and from Cabernet Franc (Vitis vinifera L.) under conditions of a hydroponic culture system. Scientia Horticulturae, 227:7984.

Davies, P.J. (2004). The Plant Hormones: Their Nature, Occurrence, and Functions. In: Davies, P.J. (ed.), Plant Hormones, Biosynthesis, Signal Transduction, Action, Kluwer Academic Publishers, Dordrecht, Netherlands, pp. 1-15.

Dawa, S.; Rather, Z.A.; Stobgais, T.; Angdus, T.; Lakdan, S. and Tundup, P. (2018). Effect of growth regulators and growth media on the rhizogenesis of some genotypes of rose through stem cuttings. Int. J. Curr. Microbiol. App. Sci., 7(1):1138-1147.

De Klerk, G.; van der Krieken, W. and de Jong, J.C. (1999). Review the formation of adventitious roots: New concepts, new possibilities. J. In Vitro Cellular and Developmental Biology Plant, 35(3):189-199.

De Klerk, G.J.; Guan, H.; Huisman, P. and Marinova, S. (2011). Effects of phenolic compounds on adventitious root formation and oxidative decarboxylation of applied indole acetic acid in Malus 'Jork 9'. Plant Growth Regul., 63:175185.

Denaxa, N.K.; Vemmos, S.N. and Roussos, P.A. (2012). The role of endogenous carbohydrates and seasonal variation in rooting ability of cuttings of an easy and a hard to root olive cultivars (Olea europaea L.). Sci. Hort., 143:19-28.

Dhaarani, V.; Rajendran, A. and Sarvalingam, A. (2017). A new mangrove associated species record (Conocarpus L. - Combretaceae) from Tamil Nadu. Current Botany, 8:166-168.
Dvin, S.R.; Moghadam, E.G. and Kiani, M. (2011). Rooting response of hardwood cuttings of MM111 apple clonal rootstock to indole butyric acid and rooting media. Asian J. App. Sci., 4(4):453-458.

Eed, A.M.; Albana'a, B. and Almaqtari, S. (2015). The effect of growing media and stem cutting type on rooting and growth of Bougainvillea spectabilis plants. Univ. Aden J. Nat. and Appl. Sc., 19(1):141147.

El Botaty, E.M. and Saleh, M.M.S. (2018). Effect of some natural substances on grape cuttings rooting. Middle East J. Agric., 7(4):1702-1709.

Elgalby, A.O.H.; Al-Edany, T.Y. and ALShewailly, M.S.R. (2011). The effect of cutting type, indole butyric acid (IBA) on rooting of Conocarpus lancifolius Engl. Basra J. Agric. Sci., 24(1):57-70.

Ercişli, S.; Anapali, Ö.; Eşitken, A. and Şahin, Ü. (2002). The effects of IBA, rooting media and cutting collection time on rooting of kiwifruit. Gartenbauwissenschaft, 67:34-38.

Erstad, J.L.F. and Gislerod, H.R. (1994). Water uptake of cuttings and stem pieces as affected by different anaerobic conditions in the rooting medium. Scientia Hort., 58(1-2):151-160.

Exadaktylou, E.; Thomidis, T.; Grout, B.; Zakynthinos, G. and Tsipouridis, C. (2009). Methods to improve the rooting of hardwood cuttings of the 'Gisela 5' cherry rootstock. HortTechnology, 19(2):254-259.

Gilani, S.A.Q.; Shah, K.; Ahmed, I.; Basit, A.; Sajid, M.; Bano, A.S. and Shahid, U. (2019). Influence of indole butyric acid (IBA) concentrations on air layerage in guava (Psidium guajava L.) cv. Sufeda. Pure and Applied Biology, 8(1):355-362.

Gilman, E.F. and Watson, D.G. (1993). Conocarpus erectus, buttonwood. Fact Sheet ST- 179. U.S. Forest Service and 


\section{S.S.A. Abdel-Rahman}

Southern Group of State Foresters, Gainesville, p. 3.

Gomez, K.A. and Gomez, A.A. (1984). Statistical Procedures for Agricultural Research. $2^{\text {nd }}$ ed. John Wily, NY, 680 p.

Grange, R.I. and Loach, K. (1983). The water economy of unrooted leafy cuttings. J. Hort. Sci., 58:9-17.

Griffin, J.J. and Schroeder, K.R. (2004). Propagation of Ulmus parvifolia "Emerald Prairies" by stem cuttings. J. Environ. Hort., 22(2):55-57.

Haissig, B.E. (1974). Influence of auxin and auxin synergist on adventitious root primodium initiation and development. New Zealand J. Forest. Sci., 4:311-323.

Hansen, J. (1986). Influence of cutting position and stem length on rooting of leaf bud cuttings of Schefflera arborieola. Scientia Hort., 28:177-186.

Hansen, J. and Moller, I. (1975). Percolation of starch and soluble carbohydrates from plant tissue for quantitative determination with anthrone. Analytical Biochemistry, 68:87-94.

Hartmann, H.T.; Kester, D.E.; Davies, F.T. and Geneve, R.L. (2014). Hartmann and Kester's Plant Propagation: Principles and Practices, $8^{\text {th }}$ ed. Prentice Hall, New Jersey, 927 p.

Hosseini, S.M.; Sadeghi, H.; Esmati, A.; Nourmohammadi, Z.; Keshavarz, M.A. and Hosseini maziani, M. (2004). Effect of media on rooting cuttings of four olive cultivars. $5^{\text {th }}$ International Symposium on Olive Growing, 27/9-2/102004, İzmir, Turkey. Abst. 234.

Jackson, M.L. (1973). Soil Chemical Analysis. Prentice-Hall, Inc. Englewood Cliffs, N.J. New Delhi, India, 498 p.

Jaleta, A. and Sulaiman, M. (2019). A review on the effect of rooting media on rooting and growth of cutting propagated grape (Vitis vinifera L.). World J. Agric. Soil Sci., 3(4):1-8.
Khandan-Mirkohi, A.; Moshrefi-Araghi, A.; Haghdoost, L.; Rashid-Rostami, F. and Sahraii, S. (2015). The effect of rooting medium, cutting type and auxin (IBA) treatment on propagation of Arizona cypress (Cupressus arizonica var. glabra). J. Sci. and Tech. Greenhouse Cult., 5(4):193-202.

Kumar, S.; Malik, A.; Yadav, R. and Yadav, G. (2019). Role of different rooting media and auxins for rooting in floricultural crops: A review. Inter. J. Chem. Studies, 7(2):1778-1783.

Kumar, V.; Singh, M.K.; Kumar, M.; Prakash, S.; Kumar, A.; Rao, S. and Malik, S. (2015). Effect of different doses of IBA and rooting media on rooting of stem cutting of lemon (Citrus limon Burm) cv. Pant Lemon-1. J. Plant Dev. Sci., 7(7):587-591.

Landis, T.D. (1995). Improving Polybag Culture for Sustainable Nurseries. Forest Nursery Notes, pp. 6-7.

Larson, E.L. (1980). Introduction to Floriculture. Academic Press London, UK, 607 p.

Leakey, R.R.B.; Chapman, V.R. and Longman, K.A. (1982). Physiological studies for tree improvement and conservation. Some factors affecting root initiation of Triplochiton scleroxylon $\mathrm{K}$. Schum. For. Ecol. Manage., 4:53-66.

Leakey, R.R.B.; Mesen, J.F.; Tchoundjeu, Z.; Longman, K.A.; Dick, J.M.P.; Newton, A.; Martin, A.; Grace, J.; Munro, R.C. and Muthoka, P.N. (1990). Low technology techniques for the vegetative propagation of tropical trees. Commonwealth. For. Rev., 69(3):247257.

Little, E.L.J. (1983). Common Fuel Wood Crops: A Handbook for Their Identification. McClain Printing Co., Parsons, West Virginia, USA, 354 p.

Liu, Z.H.; Wang, W.C. and Yen, Y.S. (1998). Effect of hormone treatment on root formation and endogenous indole-3- 
acetic acid and polyamine levels of Glycine max cultivated in vitro. Bot. Bull. Acad. Sin., 39:113-118.

Loach, K. (1996). Environmental conditions for rooting cutting: importantce, measurment and control. Acta Hortic., 374:632-636.

Mahrose, O.M. (2000). Effect of leaf retention on cuttings on rooting and vegetative growth of Ficus benjamina L. "Starlight" plants. Assiut J. Agric. Sci., 31(1):1-18.

Manila, T.; Rana, D.K. and Naithani, D.C. (2017). Effect of different growing media on vegetative growth and rooting in pomegranate (Punica granatum L.) cv. "Kandhari" hardwood stem cutting under mist. Plant Archives, 17(1):391-394.

Mohamed, A.M.A. (2005). Rooting of Grape (Vitis vinifera) Cuttings in Response to Position and Application of Rooting Hormone (IBA). M.Sc. Thesis, Fac. Agric., Khartoum Univ., Sudan, 68 p.

Mohamed, S.M.; Youssef, A.S.M. and Hegazy, N.E. (2014). Effect of IBA, rooting media and planting date on vegetative propagation of button wood tree (Conocarpus erectus L.). Annals of Agric. Sci., Moshtohor, 52(1):123-132.

Morton, J.F. (1981). Atlas of Medicinal Plants of Middle America, Bahamas to Yucatan. C.C. Thomas, Springfield, IL., University of Miami, Florida, USA, $1420 \mathrm{p}$.

Nanda, K.K. (1975). Physiology of adventitious root formation. Indian $\mathrm{J}$. Plant Physiol., 18:80-87.

Nelson, G. (1996). The Shrubs and Woody Vines of Florida. Pineapple Press, Inc., Sarasota, Fl., 391 pp.

Padekar, V.J.; Garande, V.K.; Dodake, S.S.; Sawant, S.V.; Shinde, U.S.; Sonawane, P.N.; Pawar, R.D. and Dhumal, S.S. (2018). Effect of IBA, types of cutting and rooting media on sprouting, survival percentage and growth of cuttings of
Kartoli (Momordica dioica Roxb.). Int. J. Curr. Microbiol. App. Sci., 7(10):12461260.

Palanisamy, K. and Kumar, P. (1997). Effect of position, size of cuttings and environmental factors on adventitious rooting in neem (Azadirachta indica A. Juss). Forest Ecology and Management, 98(3):277-280.

Peña-Baracaldo, F.J.; Chaparro-Zambrano, H.N.; Sierra, A.; Rodríguez, J. and Cabezas-Gutiérrez, M. (2018). Effect of different substrates and auxins on rooting of Leucadendron sp. (Proteaceae). Revista U.D.C.A. Actualidad and Divulgación Científica, 21(2):385-393.

Rajkumar, G.; Kumar, J.S.; Singh, R.; Kumar, A. and Gajender, A. (2016). Establishment, survival and growth of pomegranate cuttings with different concentrations of indole butyric acid and rooting substrates. Ecol. Environ. Cons., 22:321-327.

Rajkumar, R.; Gora, J.S.; Kumar, R.; Singh, A.; Kumar, A. and Gajender, G. (2017). Effect of different growing media on the rooting of pomegranate (Punica granatum, L.) cV. Phule Arakta cuttings. J. App. Nat. Sci., 9(2):715-719.

Rolston, S.H.; Carlos, A.F.B. and Carlos, A.P.M. (1996). Adventitious root formation and development in cuttings of Mussaenda erythrophylla L. HortScience, 31(6):1023-1025.

Rubasinghe, M.K.; Amarasinghe, K.G.K.D. and Krishnarajha, S.A. (2009). Effect of rooting media, naphthalene acetic acid and gibberellic acid $\left(\mathrm{GA}_{3}\right)$ on growth performances of Chirita moonii. Ceylon J. Sci. (Biological Sciences), 38(1):1722.

Sabalka, D. (1986). Propagation media for flats and for direct sticking: What works?. Comb. Proc. Intl. Plant Prop. Soc., 36:409-413.

Sardoei, A.S. (2014). Effect of different media of cuttings on rooting of guava 
(Psidium guajava L.). European J. Exp. Bio., 4(2):88-92.

Scagel, C.F. and Linderman, R.G. (1998). Influence of ectomycorrhizal fungi inoculation on growth and root IAA concentrations of transplanted conifers. Tree Physiol., 18:739-747.

Shiri, M.; Mudyiwa, R.M.; Takawira, M.; Musara, C. and Gama, T. (2019). Effects of rooting media and indole-3-butyric acid (IBA) concentration on rooting and shoot development of Duranta erecta tip cuttings. Afr. J. Plant Sci., 13(10):279285.

Singh, A.K.; Rajesh, S.; Mittal, A.K.; Singh, Y.P. and Shiva, J. (2003): Effect of plant growth regulators on survival rooting and growth characters in long pepper (Piper longum L.). Prog. Hort., 35:208-211.

Singh, K.K.; Choudhary, T.; Prabhat, K. and Rawat, J.M.S. (2014). Effect of IBA for inducing rooting in stem cuttings of Duranta Golden. HortFlora Research Spectrum, 3(1):77-80.

Suleiman, M.K.; Bhat, N.R.; Abdal, M.S. and Bellen, R.R. (2005). Testing newly introduced ornamental plants to the arid climate of Kuwait. Archives of Agronomy and Soil Sci., 51(1):469-479.

Tilahun, A.; Manahlie, B.; Abebe, G. and Negash, G. (2019). Effect of cutting position and indole butyric acid (auxin) concentration on rooting response of Araucaria heterophylla. African J. Biotech., 18(4):86-91.

Trobec, M.; Stampar, F.; Veberic, R. and Osterc, G. (2005). Fluctuations of different endogenous phenolic compounds and cinnamic acid in the first days of the rooting process of cherry rootstock 'Gisela 5' leafy cuttings. J. Plant Physiol., 162:589-597.

Tsipouridis, C.; Thomidis, T. and Michailides, Z. (2005). Factors influencing the rooting of peach GF677 (peach $\mathrm{x}$ almond hybrid) hardwood cuttings in a growth chamber. New
Zealand J. Crop and Hort. Sci., 33(2): 9398.

Vasco, C.; Ruales, J. and Kamal-Eldin, A. (2008). Total phenolic compounds and antioxidant capacities of major fruits from Ecuador. Food Chem., 111:816823.

Wei, G.; Tang, N.; Wei, M.; Yan, H. and Han, Y. (2017). Effects of different substrates on root development of carnation cuttings. J. Qinghai Univ., 2:07.

Wiegel, K.; Horn, H. and Hock, B. (1984). Endogenous auxin levels in terminal stem cuttings of Chrysanthemum morifolium during adventitious rooting. Physiologia Plantarum, 61(3):422-428.

Wild, A. and Jones, L.H.P. (1992). Nutrición mineral de las plantas cultivadas. En: Wild, A. (ed.). Condiciones del suelo y desarrollo de las plantas según Russel. Ediciones Mundi Prensa, Madrid, pp.73-119.

Wróblewska, K. (2015). Benzyladenine effect on rooting and axillary shoot outgrowth of Gaura lindheimeri Engelm. A. Gray cuttings. Acta Sci. Pol., Hortorum Cultus, 12(3):127-136.

Yasin, S.A. and Al-Azawi, A.H. (2019). Antibacterial activity of Conocarpus erectus leaves extracts on some microorganisms isolated from patients with burn infection. Plant Archives, 19(2):583-589.

Yeboah, J.S.T.L. and Amoah, F.M. (2009). The rooting performance of shea tree (Vitellaria paradoxa cv. Gaertn) cuttings leached in water and application of rooting hormone in different media. J. Plant Sci., 4(1):10-14.

Zhang, Z.; Wang, Z.; Zhang, Q. and Lin, R. (1998). Rapid separation and quantification of the internal hormones from Tartary buckwheat leaf using high performance liquid chromatography. Proc. VII Inter. Symposium on Buckwheat, Advances in Buckwheat Res., Winnipeg, Manitoba, Canada. 


\title{
تأثير بيئة التجذير وتركيز إندول حمض البيوتيريك على تجذير ونمو الأنواع المختلفة من العقل الساقية
} لتبات الكونوكاربس تجاير ونس

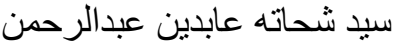 \\ قسم الزينة وتنسيق الحدائق، كلية الزرابـة عابن، جامعة أسيوط، أسيوط، مصر
}

أجريت الدراسة الحالية بهدف تقييم تأثير بيئة التجذير (طين، بيت موس + رمل، بيت موس + بيرليت،

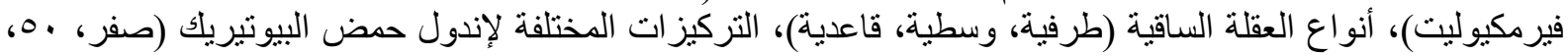

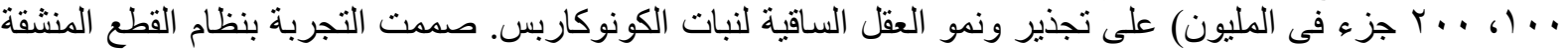

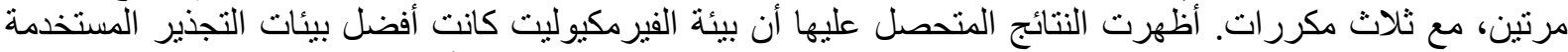

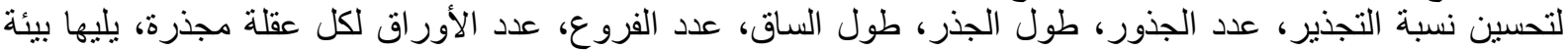

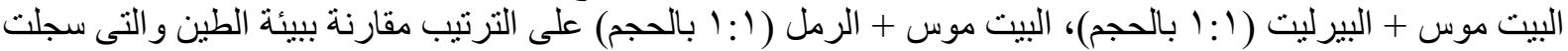

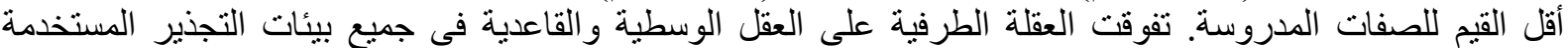

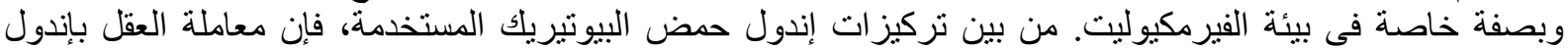

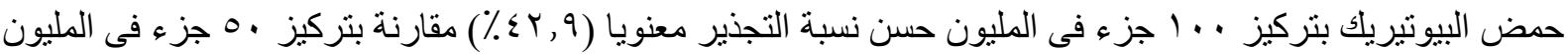

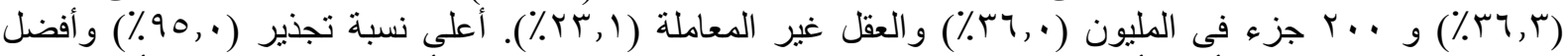

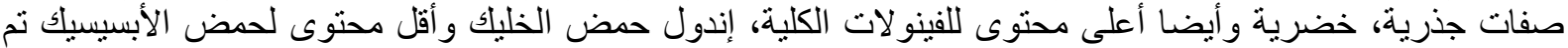

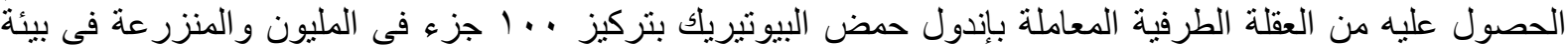

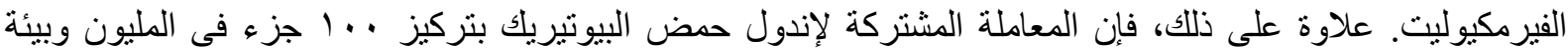

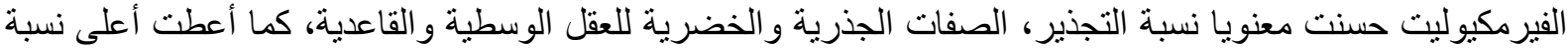

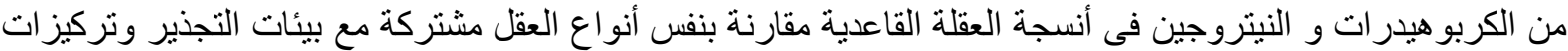

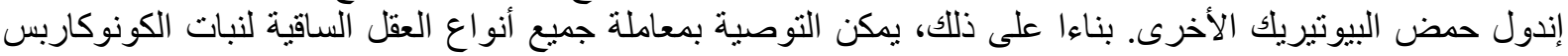

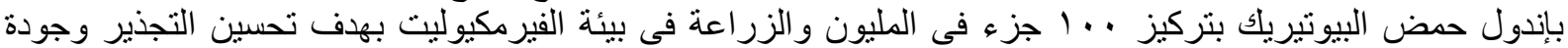

